\title{
An assessment of family variation of Norway spruce (Picea abies (L.) Karst.) of the Kolonowskie provenance from a reconstitution seed orchard
}

\author{
By H. FOBER
}

Polish Academy of Sciences, Institute of Dendrology, PL 62-035 Kórnik, Poland

(Received 14 $4^{\text {th }}$ October 2004)

\begin{abstract}
Variation in spring bud break dates and growth traits was studied among 183 half-sib families developed from Norway spruce grafts on a reconstitution seed orchard. The grafts were derived from maternal trees (ortets), which were selected on the IUFRO 1964/68 experimental plots in 11 countries. All maternal trees belong to the same provenance Kolonowskie, which should be reconstituted as a population by a seed orchard because its exact location was not documented, and thus seed of this provenance was not available. Analyses of variance of the data collected in the first six years of the experiment revealed a very high variation between families in general and between families within clones. Differences between the clones were observed in some traits (plant height after the first growing season, spring flushing in the sixth growing season), but differences between families within clones proved to be more significant. A positive correlation was found between bud break dates of grafts in the seed orchard and their generative progeny on the family experimental plot. The correlation was significant both at the family (graft) level $(p=0.01)$ and at the clonal level $(p=0.05)$. The substantial variation between open pollinated families from the reconstitution seed orchard cannot entirely be interpreted but it indicates a high selective potential of Norway spruce at the family level.
\end{abstract}

Key words: Norway spruce, reconstitution seed orchard, half-sib families, genetic variation, growth traits, spring flushing.

\section{Introduction}

Using the natural intraspecific variability of Picea abies, breeders constantly try to improve the quality and productivity of cultivated forest stands. For many decades, intensive breeding research has been conducted on the basis of large-scale provenance experiments, progeny-provenance experiments and clonal experiments with this species (KLEINSCHMit and SAUER, 1976; Dietrichson, 1979; Fowler, 1979; Giertych and KróLIKOWSKI, 1982; GIERTYCH, 1984; KLEINSChMit and SwOlBA, 1991; KRUTZsCh, 1992; BALUT and SABOR, 1993; GiertyCH and KRUPSKI, 1996). On a parallel with population selection, individual selection has been developed by identifying clones characterized by desirable breeding traits and used for establishing seed orchards. However, the genetic benefits of such selection are uncertain and can be verified only after a very long time. In fact, the selection of plus trees on the basis of phenotypic traits does not guarantee that the breeding work will be successful.

The subject of this study is the provenance Kolonowskie (IUFRO No. 0293), included in the international IUFRO 1964/68 experiment initiated by Prof. OlaF LANGLET from Sweden, on numerous experimental plots in 13 countries. Norway spruce seedlings from seeds collected in various countries were raised in a forest nursery near Hamburg in Germany under the courtesy of Prof. W. LANGNER, in the same environmental conditions and were then shipped to the countries which participated in the experiment (KRUTZSCH, 1974).

Among 1100 populations studied in that experiment, trees of the provenance Kolonowskie are characterized by very good height increments, above average in all countries. This demonstrates a great adaptive potential of that provenance in various environmental conditions (GIERTYCH, 1978). Because of this, there was and is still an interest in the provenance Kolonowskie for reforestation. Unfortunately, seeds for the IUFRO experiment were collected in an economic stand (or stands) during felling operations, so the original population does not exist anymore. Thus, plant material collected from trees of this provenance grown on the experimental plots of the IUFRO 1964/68 experiment was used to establish a reconstitution seed orchard in the experimental forest of the Institute of Dendrology at Kórnik (GIERTYCH, 1993).

The objective of the present study was to make a preliminary assessment of half-sib families, i.e. open-pollinated progenies of grafts from selected trees of the provenance Kolonowskie. The assessment focused on major growth traits and spring flushing, which determine resistance to late spring frost.

\section{Materials and Methods}

The reconstitution seed orchard at Kórnik has been composed of grafts developed from scions collected from 117 maternal trees (ortets) selected on 14 experimental plots in eleven countries. All maternal trees belong to the some provenance Kolonowskie. The maternal trees are referred to in the further text as "clones" because they have been propagated vegetatively before establishing the seed orchard. The seed orchard was established in a systematic design, ensuring the same neighbourhood of clones, i.e. theoretically a common pool of pollen (GIERTYCH, 1971).

In 1993, when the reconstitution seed orchard was 12 years old, the first cones were produced by the grafts, although only some of them formed well-developed seeds. Finally, cones were collected separately from 183 grafts representing 85 clones. Each graft was harvested separately and the seed extracted from cones of that tree constituted an open-pollinated family, denoted by a unique number. By this procedure, we got up to six families of the same clone (maternal tree). These families are half-sibs and differ only by the unknown composition of the pollen cloud due to the position of the graft in the seed orchard. Number of families (column 1) derived from studied clones (column 2), and also location of provenance plots (locality and country, columns 3 and 4 respectively), from which the clones originated are presented in the Table 1.

Seed of each family were sown in April 1994 in separate clay pots filled with a mixture of peat-based compost and gravel (1:1 $\mathrm{v} / \mathrm{v})$. The pots were placed in a greenhouse in a randomized block design. The plants were illuminated 18 hours a day, and in June and July, they were treated with nitrogen-phosphorus fertilizers. In late August, the pots with seedlings were moved outdoors and planted into the soil for winter.

In the spring of 1995, the seedlings were removed from pots, rinsed, and subjected to measurements of total fresh weight, length of the above ground part and of roots. Next, the seedlings were planted in a forest nursery. In the autumn of 
Table 1. - List of families used in experiment and localities of the provenance experiments.

\begin{tabular}{|c|c|c|c|c|c|c|c|}
\hline Family no. & $\begin{array}{l}\text { Maternal tree } \\
\text { (clone) no. }\end{array}$ & $\begin{array}{l}\text { Localities of } \\
\text { provenance exp. } \\
\text { (origin of maternal } \\
\text { tree scions) }\end{array}$ & Country & Family no. & $\begin{array}{l}\text { Maternal tree } \\
\text { (clone) no. }\end{array}$ & $\begin{array}{l}\text { Localities of } \\
\text { provenance exp. } \\
\text { (origin of maternal } \\
\text { tree scions) }\end{array}$ & Country \\
\hline 1 & 2 & 3 & 4 & 1 & 2 & 3 & 4 \\
\hline $2754,2884,2892$ & K-04-130 & Krynica & Poland & $2736,2859,2928$ & $\mathrm{~K}-31-10$ & Ilsvåg & Norway \\
\hline $2745,2758,2904$ & K-04-131 & Krynica & Poland & 2774,2836 & K-31-11 & Ilsvåg & Norway \\
\hline 2841,2961 & K-04-132 & Krynica & Poland & 2957 & K-34-02 & Salisbury & G. Britain \\
\hline 2728,2932 & K-04-134 & Krynica & Poland & $2799,2869,2870,2888$ & K-34-05 & Salisbury & G. Britain \\
\hline $2731,2738,2807$ & K-04-136 & Krynica & Poland & 2894 & K-34-07 & Salisbury & G. Britain \\
\hline 2860,2906 & K-04-137 & Krynica & Poland & 2875,2933 & $\mathrm{~K}-34-10$ & Salisbury & G. Britain \\
\hline 2832,2874 & K-04-139 & Krynica & Poland & 2749 & K-34-11 & Salisbury & G. Britain \\
\hline 2911 & K-04-140 & Krynica & Poland & 2750 & K-34-13 & Salisbury & G. Britain \\
\hline 2809,2900 & K-04-141 & Krynica & Poland & 2735,2867 & K-37-01 & Mátrafüred & Hungary \\
\hline 2901,2908 & K-04-142 & Krynica & Poland & 2796 & K-37-04 & Mátrafüred & Hungary \\
\hline 2921,2934 & K-04-143 & Krynica & Poland & 2785,2846 & K-37-05 & Mátrafüred & Hungary \\
\hline 2816,2917 & K-04-144 & Krynica & Poland & 2831 & K-37-06 & Mátrafüred & Hungary \\
\hline $2739,2781,2791,2877$ & K-04-146 & Krynica & Poland & $2773,2872,2960$ & K-37-07 & Mátrafüred & Hungary \\
\hline $2746,2824,2829,2935$ & K-04-148 & Krynica & Poland & 2817 & K-37-08 & Mátrafüred & Hungary \\
\hline $2759,2771,2879,2883,2912$ & K-04-149 & Krynica & Poland & 2898,2905 & K-37-09 & Mátrafüred & Hungary \\
\hline 2827,2920 & K-22-01 & Branson N.B. & Canada & 2903 & $\mathrm{~K}-37-10$ & Mátrafüred & Hungary \\
\hline 2808 & $\mathrm{~K}-22-02$ & Branson N.B. & Canada & $2740,2757,2766,2893$ & K-37-11 & Mátrafüred & Hungary \\
\hline $2780,2826,2897,2943,2945,2952$ & $\mathrm{~K}-24-01$ & Amance & France & $2873,2882,2910,2936$ & $\mathrm{~K}-37-12$ & Mátrafüred & Hungary \\
\hline 2881 & K-24-03 & Amance & France & 2865,2936 & $\mathrm{~K}-37-13$ & Mátrafüred & Hungary \\
\hline 2963 & K-24-04 & Amance & France & 2922 & K-37-15 & Mátrafüred & Hungary \\
\hline $2803,2821,2946$ & $\mathrm{~K}-24-05$ & Amance & France & 2855 & $\mathrm{~K}-37-17$ & Mátrafüred & Hungary \\
\hline 2828,2861 & K-24-08 & Amance & France & $2743,2755,2866$ & K-37-18 & Mátrafüred & Hungary \\
\hline $2730,2914,2925$ & K-24-09 & Amance & France & 2765 & K-38-01 & Knocktopher & Ireland \\
\hline 2899 & K-26-02 & Lisjö & Sweden & $2775,2776,2941,2955$ & $\mathrm{~K}-38-02$ & Knocktopher & Ireland \\
\hline $2751,2782,2944$ & K-26-06 & Lisjö & Sweden & 2762 & K-38-03 & Knocktopher & Ireland \\
\hline $2744,2760,2833,2962$ & K-26-07 & Lisjö & Sweden & $2767,2864,2958$ & K-38-06 & Knocktopher & Ireland \\
\hline 2918 & $\mathrm{~K}-26-08$ & Lisjö & Sweden & $2792,2844,2886$ & K-38-09 & Knocktopher & Ireland \\
\hline 2753 & K-26-09 & Abild & Sweden & 2838 & K-38-10 & Knocktopher & Ireland \\
\hline 2788,2927 & $\mathrm{~K}-26-10$ & Abild & Sweden & $2801,2851,2868$ & $\mathrm{~K}-38-11$ & Knocktopher & Ireland \\
\hline $2748,2790,2856$ & K-26-11 & Abild & Sweden & $2854,2915,2954$ & K-38-12 & Knocktopher & Ireland \\
\hline 2769,2778 & K-26-14 & Abild & Sweden & $2777,2839,2937$ & $\mathrm{~K}-38-13$ & Knocktopher & Ireland \\
\hline 2876 & K-26-15 & Abild & Sweden & 2787 & K-38-14 & Knocktopher & Ireland \\
\hline 2858 & K-26-16 & Abild & Sweden & 2847,2966 & K-38-15 & Knocktopher & Ireland \\
\hline 2804,2835 & $\mathrm{~K}-26-17$ & Abild & Sweden & 2789,2857 & K-38-17 & Knocktopher & Ireland \\
\hline 2940,2956 & K-27-03 & Zahradka & Czech Rep. & $2764,2878,2938,2948$ & K-38-22 & Knocktopher & Ireland \\
\hline 2814,2949 & K-27-04 & Zahradka & Czech Rep. & 2820 & K-39-01 & Brüggen & Germany \\
\hline 2732 & K-29-02 & Herbeumont & Belgium & 2819,2887 & K-39-02 & Brüggen & Germany \\
\hline 2931,2959 & K-31-01 & Overud & Norway & $2770,2802,2942$ & K-39-05 & Brandscheid & Germany \\
\hline 2741,2842 & K-31-03 & Overud & Norway & 2926,2951 & K-39-06 & Brandscheid & Germany \\
\hline 2737 & K-31-04 & Overud & Norway & 2794,2964 & K-39-07 & Brüggen & Germany \\
\hline 2885 & K-31-05 & Overud & Norway & $2733,2768,2805,2852$ & K-39-08 & Brandscheid & Germany \\
\hline 2913,2924 & K-31-08 & Ilsvåg & Norway & 2845,2947 & K-39-09 & Brandscheid & Germany \\
\hline 2822 & K-31-09 & Ilsvåg & Norway & & & & \\
\hline
\end{tabular}

1995 and 1996, the height of all seedlings in the nursery was measured and in the spring of 1998, 825 seedlings of 133 families (progeny of 76 clones) were planted on a family experimental plot. The young trees were spaced $1.5 \mathrm{~m} \times 2.0 \mathrm{~m}$, and the plot was established in randomized single tree plots. Bud break dates were recorded from $18^{\text {th }}$ April till $23^{\text {rd }}$ May 1999, and in the autumn of 1999, the height and current-year increments of all the seedlings were also measured. The results of measurements and observations were subjected to analyses of variance to identify statistically significant differences between experimental factors. These analyses were multivariate, hierarchical, and non-orthogonal, and the calculations were conducted according to the model presented by GIERTYCH (1991) for nonorthogonal data (Table 2). In that model, the method for estimating means of squares was based on Hick's (1973) work. In the analyses of variance, total available variability was taken into account (individual variation among seedlings as a component of variance for error). 
Table 2. - Analysis of variance and related formulae.

\begin{tabular}{|l|l|l|l|}
\hline \multicolumn{1}{|c|}{ Source of variation } & \multicolumn{1}{|c|}{$\mathrm{DF}$} & \multicolumn{1}{|c|}{ Expected mean square } & \multicolumn{1}{c|}{$\mathrm{F}$} \\
\hline Total & $\mathrm{kpqd}-1$ & & \\
Families & $\mathrm{r}-1$ & $\mathrm{~A}=\mathrm{V}_{\mathrm{D}}+\mathrm{dV}_{\mathrm{R}}$ & $\mathrm{A} / \mathrm{F}$ \\
Clones & $\mathrm{m}-1$ & $\mathrm{~B}=\mathrm{V}_{\mathrm{D}}+\mathrm{dV}_{\mathrm{Q}}+\mathrm{qdV}_{\mathrm{M}}$ & $\mathrm{B} / \mathrm{E}$ \\
Countries & $\mathrm{k}-1$ & $\mathrm{C}=\mathrm{V}_{\mathrm{D}}+\mathrm{dV}_{\mathrm{Q}}+\mathrm{qdV}_{\mathrm{P}}+\mathrm{pqdV}$ & $\mathrm{C} / \mathrm{D}$ \\
Clones in countries & $\mathrm{k}(\mathrm{p}-1)$ & $\mathrm{D}=\mathrm{V}_{\mathrm{D}}+\mathrm{dV}_{\mathrm{Q}}+\mathrm{qdV}$ & $\mathrm{D} / \mathrm{E}$ \\
Families in clones in countries & $\mathrm{kp}(\mathrm{q}-1)$ & $\mathrm{E}=\mathrm{V}_{\mathrm{D}}+\mathrm{dV}_{\mathrm{Q}}$ & $\mathrm{E} / \mathrm{F}$ \\
Trees in families in clones in countries & $\mathrm{kpq}(\mathrm{d}-1)$ & $\mathrm{F}=\mathrm{V}_{\mathrm{D}}$ & \\
\hline
\end{tabular}

Symbols used

$r \quad$ - number of families

$\mathrm{m}$ - number of clones

$\mathrm{k}$ - number of countries

p - number of clones within countries

$q-$ number of families within clones within countries

d - number of trees within families within clones within countries

$\mathrm{V}_{\mathrm{R}}$ - families variance

$\mathrm{V}_{\mathrm{M}}$ - clones variance

$\mathrm{V}_{\mathrm{K}}^{\mathrm{M}}$ - countries variance

$\mathrm{V}_{\mathrm{P}}$ - clones within countries variance

$\mathrm{V}_{\mathrm{Q}}$ - families within clones within countries variance

$\mathrm{V}_{\mathrm{D}}^{\mathrm{Q}}$ - trees within families within clones within countries variance

$\mathrm{DF}$ - degrees of freedom

F - F-test

\section{Results}

\section{First year of the experiment}

In the first growing season, the experiment involved 2390 seedlings representing unevenly 183 open-pollination families from 85 clones. The mean height of seedlings at the end of the first growing season was $8.6 \mathrm{~cm}$. A significant $(p=0.01)$ variance in this trait was observed between families and clones (Table 3), also between families within clones. Plant height did not depend on location of provenance plots (countries), where the maternal trees were selected. Clonal means of plant height ranged from $3.7 \mathrm{~cm}$ to $11.5 \mathrm{~cm}$, while family means ranged from $3.4 \mathrm{~cm}$ to $13.7 \mathrm{~cm}$ (Table 5$)$.
Root length at the end of the first season varied from $9.9 \mathrm{~cm}$ to $24.3 \mathrm{~cm}$, on average $17.9 \mathrm{~cm}$ (Table 5). In respect of this trait, significant differences were found both between families in general and between families within clones, while differences between the clones and between countries of origin of the clones were not significant (Table 3).

Fresh weight of whole seedlings was independent of any experimental factors (Table 3) and reached on average $799 \mathrm{mg}$ (Table 5).

\section{Second year of the experiment}

After transplantation from pots and during growth in the nursery, some seedlings died, so after two growing seasons

Table 3. - F-test after variance analysis and the level of significance. Characters of seedlings at age 1 - and 2-years.

\begin{tabular}{|c|c|c|c|c|}
\hline \multirow{2}{*}{ Source of variation } & \multicolumn{3}{|c|}{ 1-year old seedlings } & \multirow{2}{*}{$\begin{array}{c}\text { 2-year old } \\
\text { seedlings }\end{array}$} \\
\hline & Height & Root length & Fresh weight & \\
\hline Families & $14.99 * *$ & $3.42 * *$ & - & $5.14 * *$ \\
\hline Clones & $1.63 * *$ & $1.08 \mathrm{~ns}$ & $1.21 \mathrm{~ns}$ & $1.09 \mathrm{~ns}$ \\
\hline Countries & $1.26 \mathrm{~ns}$ & 0.77 & $1.72 \mathrm{~ns}$ & 0.34 \\
\hline Clones in countries & $1.58 *$ & $1.11 \mathrm{~ns}$ & $1.08 \mathrm{~ns}$ & $1.19 \mathrm{~ns}$ \\
\hline Families in clones in countries & $11.63 * *$ & $3.31 * *$ & - & $4.92 * *$ \\
\hline DF for: total & 2389 & 1835 & 179 & 1333 \\
\hline families & 182 & 176 & - & 159 \\
\hline clones & 84 & 82 & 83 & 80 \\
\hline countries & 10 & 10 & 10 & 10 \\
\hline
\end{tabular}

\footnotetext{
** - significant at 0.01

* - significant at 0.05

ns - non significant

$\mathrm{DF}$ - degrees of freedom
} 
1334 plants of 160 families were left. Their mean height amounted then to $11.6 \mathrm{~cm}$ (Table 5) and analysis of variance revealed significant differences $(p=0.01)$ between families in general and between families within clones (Tables 3). No significant differences were observed between the offspring of clones and countries of origin of the clones. Family means of plant height ranged from $4.8 \mathrm{~cm}$ to $18.7 \mathrm{~cm}$ (Table 5).

\section{Third year of the experiment}

After the third growing season, the seedlings still growing in the nursery, were from $7.7 \mathrm{~cm}$ to $36.4 \mathrm{~cm}$ high, and the mean value was $21.0 \mathrm{~cm}$ (Table 5). Families in general and within clones differed significantly $(\mathrm{p}=0.01)$ (Table 4).

\section{Sixth year of the experiment}

Plant height after six growing seasons (including two seasons on experimental plots after transplantation from the nursery) showed great differences between families in general and between families within clones (Table 4). The general mean was $78.2 \mathrm{~cm}$, while family means ranged from $37.5 \mathrm{~cm}$ to $113.3 \mathrm{~cm}$ (Table 5). The mean current-year height increment in 1999 was very large, amounting to $28.4 \mathrm{~cm}$ on average (Table 5), i.e. it accounted for about $36 \%$ of the total plant height at the end of that season. The increment in absolute values varied from $7.5 \mathrm{~cm}$ to $52.7 \mathrm{~cm}$ (Table 5). Analysis of variance showed significant differences $(p=0.01)$ between families in general and between families within clones (Table 4).

Table 4. - F-test after variance analysis and the level of significance. Characters of seedlings at age 3- and 6-years.

\begin{tabular}{|c|c|c|c|c|}
\hline \multirow[b]{2}{*}{ Source of variation } & & & \multicolumn{2}{|c|}{1999 year } \\
\hline & Height & Height & $\begin{array}{c}\text { Current } \\
\text { annual } \\
\text { increment } \\
\text { of height }\end{array}$ & $\begin{array}{c}\text { Start of } \\
\text { flushing }\end{array}$ \\
\hline Families & $7.95 * *$ & $3.70 * *$ & $1.98 * *$ & $2.55 * *$ \\
\hline Clones & $1.15 \mathrm{~ns}$ & 0.96 & $1.15 \mathrm{~ns}$ & $2.59 * *$ \\
\hline Countries & 0.61 & $1.07 \mathrm{~ns}$ & $1.14 \mathrm{~ns}$ & 0.56 \\
\hline Clones in countries & $1.21 \mathrm{~ns}$ & 0.95 & $1.13 \mathrm{~ns}$ & $2.74 * *$ \\
\hline Fam. in clones in countries & $7.37 * *$ & $3.78 * *$ & $1.82 * *$ & $1.38 *$ \\
\hline DF for: total & 1071 & 824 & 751 & 852 \\
\hline families & 150 & 132 & 132 & 151 \\
\hline clones & 78 & 75 & 74 & 81 \\
\hline countries & 10 & 10 & 9 & 10 \\
\hline
\end{tabular}

See explanations for Table 3 .

${ }^{1)}$ score in days from the first day of flushing ( $18^{\text {th }}$ April)

Table 5. - Mean values for studied traits and ranges of variation for families and clones of maternal trees. Bold letters indicate statistical significant differences.

\begin{tabular}{|c|c|c|c|c|c|}
\hline \multirow[t]{2}{*}{ Traits } & \multirow[b]{2}{*}{ Mean } & \multicolumn{2}{|c|}{ Family range } & \multicolumn{2}{|c|}{ Clonal range } \\
\hline & & $\min$. & $\max$. & $\min$. & $\max$. \\
\hline Seedling height at 1-year $(\mathrm{cm})$ & 8.6 & 3.4 & - $\quad 13.7$ & 3.7 & 11.5 \\
\hline Seedling root length at 1 -year $(\mathrm{cm})$ & 17.9 & 9.9 & $-\quad 24.3$ & 11.4 & 23.6 \\
\hline Fresh weight at 1 year $(\mathrm{mg})$ & 799 & 267 & - 1550 & 329 & - 1925 \\
\hline Seedling height at 2 year $(\mathrm{cm})$ & 11.6 & 4.8 & -18.7 & 4.8 & 18.4 \\
\hline Seedling height at 3 year $(\mathrm{cm})$ & 21.0 & 7.7 & -36.4 & 7.7 & 33.6 \\
\hline Height of trees at 6 year $(\mathrm{cm})$ & 78.2 & 37.5 & -113.3 & 50.0 & -111.5 \\
\hline $\begin{array}{l}\text { Current annual increment of height } \\
\text { in } 1999(\mathrm{~cm})\end{array}$ & 28.4 & 7.5 & 52.7 & 7.5 & 44.5 \\
\hline Start of flushing ${ }^{1)}$ & 14.0 & 1.0 & $-\quad 24.3$ & 5.5 & $-\quad 21.5$ \\
\hline Date ${ }^{2)}$ & $1 . \mathrm{V}$ & 18.IV & $-11 . V$ & 21.IV & $-\quad 9 . V$ \\
\hline
\end{tabular}

1) score in days from the first day of flushing

2) dates in April (IV) and May (V) 1999 
Spring flushing (i.e. time of initiation of bud development) varied considerably in 1999, from $18^{\text {th }}$ of April till $23^{\text {rd }}$ of May. The mean date for the whole experiment was $1^{\text {st }}$ of May (Table 5). Analysis of variance revealed significant differences $(p=0.01)$ not only between families in general and between families within clones, but also between clones (Table 4). Family means ranged from $18^{\text {th }}$ of April till $11^{\text {th }}$ of May, while clone means from $21^{\text {st }}$ of April till $9^{\text {th }}$ of May (Table 5).

Results of observations of flushing initiation, conducted in the same year in the seed orchard from which the seed were collected for the present experiment, revealed significant differences between clones. Their flushing dates ranged from $25^{\text {th }}$ of April till $20^{\text {th }}$ of May. A significant $(p=0.01)$ positive correlation was found between flushing dates of the clones in the seed orchard and of their offspring on the experimental plot. The value of the correlation coefficient was $r=0.341(n=136)$ at the family (graft) level and $\mathrm{r}=0.371(\mathrm{n}=75)$ at the clonal level.

On the family experimental plot also flushing date and plant height were positively correlated: the later the flushing the higher plants. The correlation coefficients reached $\mathrm{r}=0.381$ $(\mathrm{n}=133, \mathrm{p}=0.01)$ at the family level and $\mathrm{r}=0.284(\mathrm{n}=76$, $\mathrm{p}=0.05)$ at the clone level.

\section{Discussion}

The international provenance experiment IUFRO 1964/1968, being the source of material for this study, included 96 Polish populations. Among them, provenance Kolonowskie is particularly noteworthy as its growth parameters exceeded average values on all 14 experimental plots in 11 countries (GIERTYCH, 1993). This means that this population can easily adapt to various environmental conditions. We know nothing about the composition of the original population. Only its success in many areas makes it interesting. Its possible compositionary nature may be a tentative conclusion.

The 85 trees, whose grafts and offspring were used in the experiment presented here, were selected on most of the IUFRO experimental plots (Table 1). They grow in highly varied climatic conditions, which is evidenced by the broad ranges of geographical coordinates and altitude of the plots.

Analyses of variance of the measurements of growth traits carried out in 1994-1999 revealed substantial differences between families in general. Statistically significant differences were found also between clones, but the greatest variation was observed between families within clones. The variation is not a result of lost of scions by grafts and the rootstock developing. In spruce the ramet is clearly different from the rootstock and these two can be easily distinguished. This is probably due to variation in the pool of paternal gametes in spite of the systematic lay-out of the reconstitution seed orchard. Because of the young age of the plantation, the trees produced very small amounts of pollen and many clones did not produce pollen at all. Thus it is highly probable that alien pollen from old single trees in the vicinity clearly dominated in pollination of that orchard that year (1993). No inbreeding rate was estimated, however the pollen cloud was expected to be more or less homogenous.

The observed significant variation in growth traits and spring flushing time indicates a considerable selective potential within the reconstituted provenance Kolonowskie at the family level. Selection for late flushing is particularly important for Norway spruce breeders and would enable them to choose appropriate genotypes and prevent losses caused by late spring frost. This is consistent with results of earlier research. For example, SABOR (1984) found that provenance Kolonowskie, similar as populations from NE Poland or the provenance
Radom from central Poland, was characterized by late flushing dates on the IUFRO 1964/68 experimental plot at Krynica, Poland. The ranking of spring flushing dates of different provenances is always the same, irrespective of location of the experimental plot (GIERTYCH, 1998). Thus the selection of late flushing phenotypes within the reconstituted provenance Kolonowskie is possible and sensible, considering the broad range of genetic variation of that trait which was revealed in this study.

\section{Literature}

BALUT, S. and SABOR, J. (1993): Current state of investigation in the international provenance test of Norway spruce IUFRO 1964/68 in Krynica/site N19, Poland/. In Rone V. (Ed.) Proc. IUFRO S2.2-11 Symp. "Norway spruce provenances and breeding", Riga, Latvia: 6-33.

DiETRICHSON, J. (1979): Norway spruce provenance trials in nordic countries. Proc. IUFRO Joint Meeting of Working Parties on Norway Spruce Provenances and Norway Spruce Breeding, Bucharest 1979, Publ. LSFRI, Escherode, FRG: $3-14$.

FowleR, D. P. (1979): Norway spruce provenance experiments in North America. Proc. IUFRO Joint Meeting of Working Parties on Norway Spruce Provenances and Norway Spruce Breeding, Bucharest 1979, Publ. LSFRI, Escherode, FRG: $29-40$.

GieRTych, M. (1971): Systematic lay-outs for seed orchards (Short note). Silvae Genetica 20 (4): 137-138.

GIERTYCH, M. (1978): Plastyczność polskich ras świerka (Picea abies (L.) Karst.) w świetle międzynarodowego doświadczenia IUFRO z lat 1964-1968. Arboretum Kórnickie 23: 187-206.

GIERTYCH, M. (1984): Report on the IUFRO 1938 and 1939 provenance experiments on Norway spruce (Picea abies (L.) Karst.). Published by Polish Academy of Sciences, Institute of Dendrology, Kórnik, Poland.

GIERTYCH, M. (1991): Selekcja proweniencyjna, rodowa i indywidualna $\mathrm{w}$ doświadczeniach wieloczynnikowych ze świerkiem pospolitym (Picea abies (L.) Karst.). Arboretum Kórnickie 36: 27-42.

GierTyCH, M. (1993): Breeding Norway spruce in Poland: from provenance tests to seed orchards. Norway spruce provenances and breeding. Proceedings of IUFRO (S2.2-11) Symposium, Latvia, 1993: 193-199.

GIERTYCH, M. and KRUPSKI, P. (1996): Analiza produktywności polskich proweniencji świerka (Picea abies (L.) Karst.) na czterech krajowych powierzchniach doświadczalnych. Arboretum Kórnickie 41: 59-74.

GIERTYCH, M. and Królikowski, Z. (1982): Doświadczenie nad zmiennością populacyjną i rodową świerka pospolitego $\mathrm{z}$ różnych części Polski. Arboretum Kórnickie 26: 307-350.

Hicks, C. R. (1973): Fundamental Concepts in the Design of Experiments. Holt, Rinehart and Winston, New York.

KleINSChMit, J. and SAUER, A. (1976): Variation in Morphology, Phenology and Nutrient Content Among Picea abies Clones and Provenances, and its implications for Tree Improvement. In: Tree Physiology and Yield Improvement. Academic Press London, New York, San Francisco, Editor Cannel/Last.: 503-517.

KLEINSChMit, J. and SvolBA, J. (1991): Variation im Wachstum von Fichtenstecklingen (Picea abies (L.) Karst.) in Niedersachsen. Allg. Forst u. Jagdztg 162 (1): 7-12.

KRUTZSCH, P. (1974): The IUFRO 1964/68 provenance test with Norway spruce (Picea abies (L.) Karst.). Silvae Genetica 23: $58-62$.

KRUTZSCH, P. (1992): IUFRO's role in coniferous tree improvement: Norway spruce (Picea abies (L.) Karst.). Silvae Genetica 41 (3): 143-150.

SABOR, J. (1984): Pędzenie wiosenne świerka pospolitego (Picea abies (L.) Karst.) w rocznym cyklu przyrostowym proweniencji objętych doświadczeniem ITPNS-IUFRO 1964/68 w Krynicy. Acta Agraria et Silvestria, Ser. Silv. 23: 53-69. 